\title{
Acid Mine Drainage Potential of the Coral Snake Waste Dump, Anglogold Ashanti, Obuasi Mine*
}

\author{
S. Ndur, N. Amegbey, J. Agyeman and V. Frempong
}

Ndur, S. Amegbey, N. Agyeman, J. and Frempong, V. (2010), "Acid Mine Drainage Potential of the Coral Snake Waste Dump, Anglogold Ashanti, Obuasi Mine”, Ghana Mining Journal, Vol. 12, pp. 32 - 37.

\begin{abstract}
This paper assessed the Acid Mine Drainage (AMD) potential of the Coral Snake Waste Dump located close to the Enkansu and Kaw streams in Obuasi. Ten water and fifty rock samples were analysed for physico-chemical parameters. Acid Base Accounting (ABA) determinations using static methods were employed to ascertain AMD potential of the dump. The modified ABA and the High Temperature Combustion methods were used to determine the Neutralisation Potential (NP) and the Maximum Potential Acidity (MPA) of the various rocks at the dump. The Net Neutralisation Potential (NNP) and Neutralisation Potential Ratio (NPR) of the rocks were calculated from the values of the NP and MPA. The pH of the streams ranges between 7.09 and 7.81. As and $\mathrm{Pb}$ concentrations in the streams were above WHO limits for drinking water. The major constituents of the waste dump; phyllites and greywacke constituting about $75.0 \%$ of rocks are not acid generating. The schist and oxide minerals have negative NNP and MPA implying that they are acid generating. However, quartzite analysis indicates they lie in the uncertainty zone. The results show that the Coral Snake Waste dump is not acid generating, although $\mathrm{As}$ and $\mathrm{Pb}$ levels in streams are issues of major concern.
\end{abstract}

\section{Introduction}

Acid Mine Drainage (AMD) occurs when mine rock and tailings material containing sulphidebearing minerals such as pyrite and pyrhothitte are exposed to molecular oxygen-rich environment and water (Warhurst and Noronha, 2000; Cambridge, 1996, Nordstrom and Alpers, 1999). The resultant acidic effluent typically contains high concentrations of $\mathrm{Fe}^{3+}$ ion, which is capable of leaching heavy metals present in the host rocks or tailings material (Gould and Kapoor, 2003, Blowes et al., 2005, Ptacek and Blowes, 2005). This phenomenon can lead to serious contamination of soil, surface and subsurface water by lowering their $\mathrm{pH}$, increasing soluble heavy metals concentrations and modifying substrates. Fauna and flora can also be impacted adversely by acute or chronic toxicity accompanied by dessimation of sensitive species with niche loss, simplification of the food chain, and hence creation of ecological instability (Pasco et al., 1994; Edmunds and Smedley, 1996).

These detrimental impact of AMD on the environment make it an undesired phenomenon to both the mining companies and the people living in the surrounding communities, especially in developing countries like Ghana where the resources and technology are not readily available to mitigate the impacts sustainably. Once it starts, its mitigation is not only difficult but also costly. Hence, it is envi ronmentally safer and economically beneficial to prevent its occurance.

Kuma (2003) and Asamoah et al. (2007) reported the occurence of AMD in the Tarkwa mining area in Ghana. Though these studies focused on waste rocks found in the middle Precambrian Tarkwaian System, it is also important to ascertain the AMD potential of waste rocks from the Lower Birimian rock system of Ghana. AngloGold Ashanti (AGA) Obuasi mine is located in the Birimian rock system and curently operating the largest Bacteria Oxidation (BIOX) Sulphide Treatment Plant (STP) in the world. The ores contain gold bearing sulphide minerals. Gold has been extensively mined from sulphide ores in Obuasi for over a century now. The possible impact of mining activities such as the acid formation and drainage into streams and transportation of heavy metals such as As, Zn, $\mathrm{Cu}, \mathrm{Pb}$, and $\mathrm{Fe}$ associated with gold may only be felt in the future. Of particular interest in the present work is the Coral Snake Waste Dump at Obuasi.

The Coral Snake Waste Dump is located to the east of Anyinam Shaft and to the south of West shaft (Figure 1). It is bounded on the north east by the Enkansu stream and the south by the Kaw stream. It contains 40 million tonnes of waste rocks mostly from a series of open-pits mined in the 1990s as well as from the underground mines. Portions of the waste dump cover part of Enkansu

\footnotetext{
* Manuscript received September 09, 2009

Revised version accepted October 10, 2010
} 


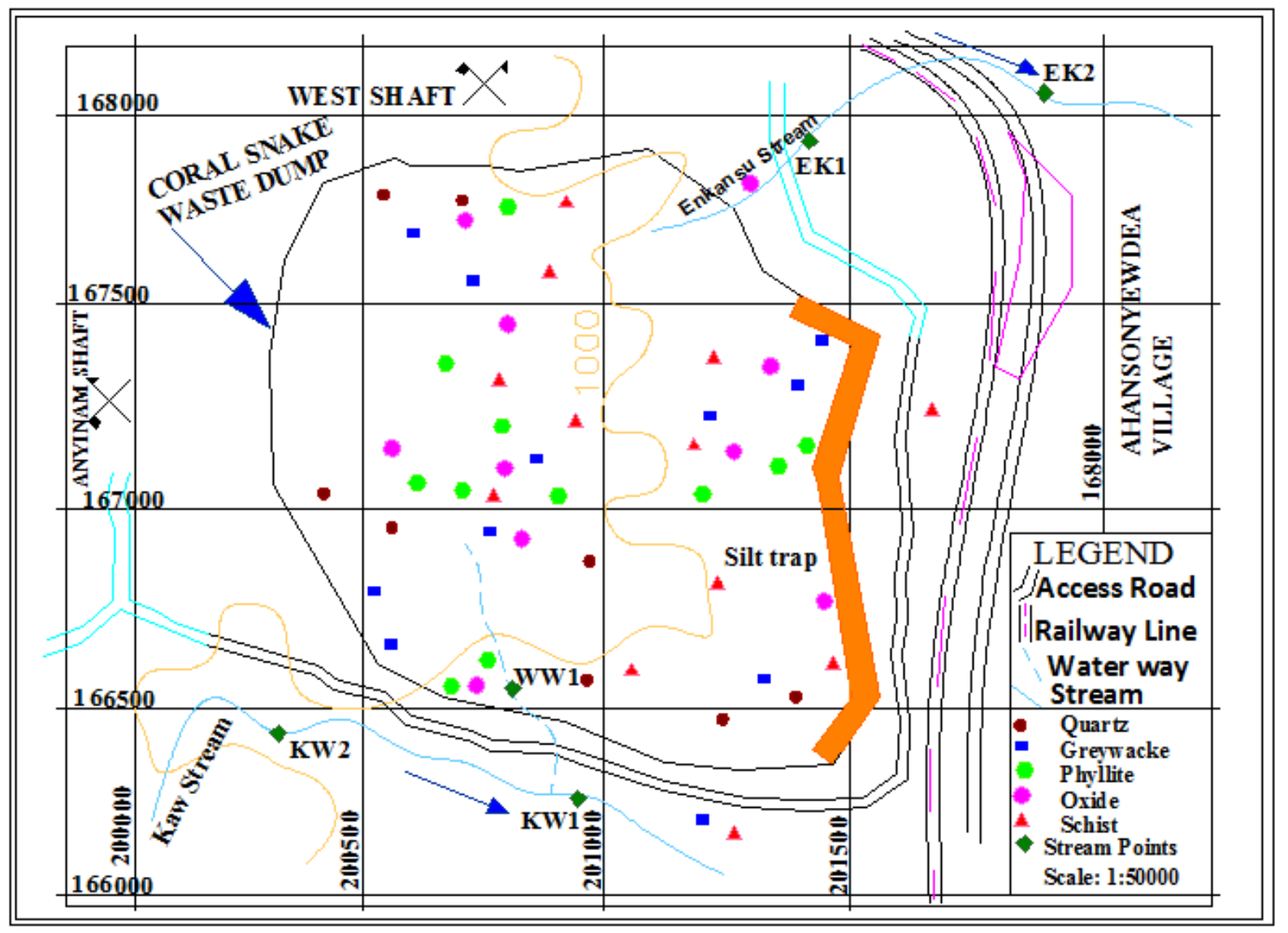

Fig. 1 Location of Coral Snake Waste Dump Showing Sampling Points

stream at the source. A drainage (WW1) from the waste pile flows directly into the Kaw stream. Surface run-offs through the waste dump also flow into these streams. Flooding of Ahansoyewodea, a village located at the north-eastern end of the dump about $400 \mathrm{~m}$ downstream of the Enkansu stream, during a heavy rainfall season is possible. In addition, the drainage from the waste dump may contain pollutants that can pose a threat not only to aquatic life in the water bodies but also to downstream water users.

Since the construction of the dump 17 years ago, no study has been conducted to investigate its impact with respect to AMD. This paper attempts to investigate the AMD potential at Coral Snake Waste Dump of AGA Obuasi Mine. Findings from the investigations will assist the management of AGA Obuasi to manage seepage from the dump.

\section{Sampling, Analytical Methods and Results}

A sampling campaign was undertaken during which rock samples from the waste dump were taken in such a way that they represent the different rock formations present. Water samples were taken from streams where seepage from the waste dumps flowed into.

\subsection{Sampling}

Fifty samples, ten each of five waste rock types (schist, phyllites, greywacke, quartzites and oxides), were picked randomly from the waste dump for optical and scanning electron microscopy (SEM) examinations. Total sulphur determination and modified ABA analysis were also carried out. A Sokkia Total Station Set5/30R was used to record sample point locations as shown in Fig. 1.

Ten surface water samples were collected from the Enkansu and Kaw streams at points EK1, EK2, KW1 and KW2 (Fig. 1). Points EK2 and KW2 are control points. Point WW1 located in the water way emanating from the dump to the Kaw stream was also sampled (Fig. 1). The samples were taken following the method prescribed by Greenberg et al. (1992). Sterilised plastic bottles were carefully rinsed three times at each sampling station before being filled with the sample water.

\subsection{Analytical Methods and Results}

The identification of the rocks was carried out at the Geological Department of the Mine. The waste 
Table 1 Results of Analysis of Surface Water and Coral Snake Waste Rock

\begin{tabular}{|c|c|c|c|c|c|c|}
\hline Parameter & $\mathbf{p H}$ & $\mathbf{A s}$ & $\mathbf{F e}$ & $\mathbf{C u}$ & $\mathbf{P b}$ & $\mathbf{Z n}$ \\
\hline Coral Snake Waste Dump & - & 5.49 & 14.53 & 1.38 & 0.30 & 1.02 \\
\hline EK1 & 7.79 & 0.11 & 0.05 & 0.01 & 0.06 & 0.01 \\
\hline EK2 & 7.81 & 0.12 & 0.06 & 0.01 & 0.05 & 0.02 \\
\hline KW1 & 7.09 & 0.09 & 0.06 & 0.01 & 0.03 & 0.01 \\
\hline KW2 & 7.14 & 0.10 & 0.06 & 0.01 & 0.03 & 0.02 \\
\hline WW1 & 7.11 & 0.09 & 0.06 & 0.01 & 0.02 & 0.01 \\
\hline WHO Standard Values & $6.50-8.50$ & 0.01 & 0.10 & 3.00 & 0.01 & 1.5 \\
\hline
\end{tabular}

Table 2 Results of Microscopic and SEM Analysis of Coral Snake Waste Rock

\begin{tabular}{|c|c|c|c|c|c|}
\hline Classification & Rock Type & Major Minerals & & Minor Minerals & \\
\hline Meta-Sediment & $\begin{array}{l}\text { Phyllites } \\
\text { Schists } \\
\text { Grewackes }\end{array}$ & $\begin{array}{l}\text { Quartz } \\
\text { Dolomite-ferroan and } \\
\text { Ankerite } \\
\text { Calcite, Chlorapatite and } \\
\text { Micas }\end{array}$ & $\begin{array}{l}20 \% \\
50 \%\end{array}$ & $\begin{array}{l}\text { Plagioclase Feldspar } \\
\text { (albite- rich) } \\
\text { Sericite, Chlorite, Humite } \\
\text { Arsenopyrite and Zircon }\end{array}$ & $20-30 \%$ \\
\hline Meta-Volcanic & $\begin{array}{l}\text { Quartzites } \\
\text { Oxides }\end{array}$ & $\begin{array}{l}\text { Quartz } \\
\text { Calcite, Chlorapatite, } \\
\text { loellingite } \\
\text { Dolomite-ferroan and } \\
\text { Ankerite } \\
\text { Arsenopyrite, Pyrite, Micas } \\
\text { and Rutile }\end{array}$ & $\begin{array}{l}20 \%, \\
50 \%\end{array}$ & $\begin{array}{l}\text { Augite (Clinopyroxene) } \\
\text { Sulfosalts }\end{array}$ & $35 \%$ \\
\hline
\end{tabular}

Table 3 ABA Results for Coral Snake Waste Rock Samples

\begin{tabular}{|c|c|c|c|c|c|c|c|c|c|c|}
\hline \multirow[b]{2}{*}{ Rock Type } & \multicolumn{3}{|c|}{$\mathbf{N P}$} & \multicolumn{3}{|c|}{ MPA } & \multirow{2}{*}{$\begin{array}{c}\text { NNP } \\
\text { Acid }<0-12< \\
\text { Alkaline* }\end{array}$} & \multirow{2}{*}{$\begin{array}{c}\text { NPR } \\
\text { Acid }<1-2< \\
\text { Alkaline* }\end{array}$} & \multirow{2}{*}{$\begin{array}{l}\text { Qty } \\
\text { (MT) }\end{array}$} & \multirow[b]{2}{*}{$\%$} \\
\hline & Min & Max & Mean & Min & Max & Mean & & & & \\
\hline Quartz & -12.50 & 102.72 & 17.80 & 0.94 & 43.13 & 7.97 & 9.83 & 2 & 2 & 5 \\
\hline Greywacke & -10.75 & 271.75 & 52.55 & 1.60 & 8.10 & 3.85 & 48.70 & 14 & 10 & 25 \\
\hline Oxide & -21.25 & 14.00 & -3.53 & 0.90 & 5.90 & 3.60 & -7.13 & 1 & 3.2 & 8 \\
\hline Phyllites & -6.50 & 270.45 & 39.52 & 1.60 & 35.30 & 9.63 & 29.89 & 4 & 20 & 50 \\
\hline Schist & -270.00 & 2.75 & -32.18 & 1.30 & 150.60 & 18.26 & -50.44 & 2 & 4.8 & 12 \\
\hline
\end{tabular}

*Values falling between the ranges for both NNP and NPR can be either an acid or alkalinity producer.

rock samples were initially crushed to $4 \mathrm{~mm}$ and then pulverised to $75 \mu \mathrm{m}$ for the determination of both the Neutralising Potential (NP) and the concentration of some selected metals. The results of selected metals concentration are given in Table 1.

The water samples were analysed the same day at the Environmental Laboratory of AGA. The $\mathrm{pH}$ of the water samples were measured in the field with a Fisher Brand Hydrus 100 Electrometer. Aquaregia digestion, followed by a flame Atomic Absorption Spectroscopy (AAS) analysis on VARIAN 220, was used to determine the concentrations of the selected heavy metals in both the water and waste rocks samples. The results are also summarised in Table 1. 
From the microscopic and SEM analysis, the rocks on the waste dump can be broadly classified into meta-sediments (phyllites, schists and grewackes) and meta-volcanics (quartzites and oxides). The major minerals in the former include quartz, dolomite-ferroan and ankerite which form about $50 \%$. Others are calcite, chlorapatite and micas. The minor minerals are plagioclase feldspar (albite rich) which constitute about $20-30 \%$, sericite, humite zircon, chlorite and traces of arsenopyrites that are randomly distributed in its matrices (Table 2).

The modified Acid Base Accounting (ABA) static test procedure was used to determine the Neutralisation Potential (NP) of the rocks, while the Maximum Potential Acidity (MPA) was determined using the High Temperature Combustion Method ASTM D4329. The MPA tests establish the maximum amount of sulphuric acid produced from sulphidic wastes. This is measured by analysing the sample for its sulphur content (Brady and Smith, 1990). The Total Sulphur $\left(\mathrm{S}_{\mathrm{T}}\right)$ present in the rock samples was calculated using the formula in Equation 1:

Both Net Neutralisation Potential (NNP) and Neutralisation Potential Ratio (NPR) are derivatives of NP and MPA. The NNP and NPR were calculated from equations 2 and 3 respectively:

$\mathrm{S}_{\mathrm{T}}(\%)=\frac{\text { Borax Titre } \times \text { Borax Concentration }}{\text { Weight of sample }} \times 100 \%$
$\mathrm{NNP}=\mathrm{NP}-$ MPA

$\mathrm{NPR}=\frac{\mathrm{NP}}{\mathrm{MPA}}$

The mean values of ABA obtained are shown in Table 2.

\section{Discussions}

The presence of secondary minerals like sericite and calcite and the amorphous shape of the mineral grains suggest that alteration or weathering is occurring in the rocks. Mineralogical study of the latter identified quartz about $20 \%$, dolomiteferroan and ankerite about 50\%, chlorapatite, micas, arsenopyrite, pyrrhotite, pyrite and rutile as major minerals. Augite (clinopyroxene) is a minor mineral in the meta-volcanic but found only in the oxide (dolerite) and a host of other minor minerals like sulfosalts identified by SEM analysis in the quartzite.

\subsection{Rock Analysis and ABA}

The most dominant metal in the rocks is Fe (14.53 $\mathrm{ppm}$ ) probably because it is present in most of the major and minor minerals found in all the rocks. This is followed by As (5.49 ppm), Cu (1.38 ppm) possibly from chalcopyrite and some sulfosalts in the quartzite, $\mathrm{Zn} \mathrm{(1.02} \mathrm{ppm)} \mathrm{may} \mathrm{be} \mathrm{from}$ sphalerite found in the quartzite and $\mathrm{Pb}(0.30 \mathrm{ppm})$ in that order. The concentrations of metals in the streams are low compared to their corresponding values in the rocks (Table 1) which is to be expected. The high concentrations of $\mathrm{As}$ and $\mathrm{Pb}$ may not be coming from the waste rocks but from the natural soils of Obuasi area (Kumi, 1988). It is known that most metals are insoluble at neutral $\mathrm{pH}$ and hence precipitate out of solution.

Two million tonnes of rocks from the dump representing $5.0 \%$ are quartzite. Samples of these rocks gave NP values ranging from -12.50 to 102.75 with a mean of 17.80 while the MPA ranges from 0.94 to 43.13 with a mean value of 7.97. According to Perry and Brady (1995), if the NNP of a rock is between 0 and 12 its acidity cannot be predicted whereas if the NNP is greater than 12, then the rock is alkaline producer. From Table 2, the NNP of 9.83 suggests that a rock is either an acid or alkaline producer. The NPR is 2 and according to the criteria set by Skousen et al. (1987), an NPR from 1 to 2 is either an acid or alkaline producer. The monominellic nature of quartzite and the presence of minor sulphide minerals and sulfosalts which are non acid generating largely account for its uncertainty (Amanor and Gyapong, 1998).

About $25.0 \%$ of the rocks at the dump (about 10 million tonnes) are greywacke (Table 2). The greywacke gave NP values ranging from -10.75 to 271.75 with a mean of 52.55 while the MPA ranges from 1.60 to 8.10 with a mean value of 3.85. Thus a NNP of 48.70 indicates an alkaline producer, likewise is its NPR value of 14 . Greywacke are meta-sediment rocks, which contain about $50 \%$ of carbonate materials including dolomite-ferroan and ankerite and traces of arsenopyrite. Hence the carbonate content is sufficient to buffer any acid that may be generated during sulphide oxidation.

The oxides are about 3.2 million tonnes or $8.0 \%$ component of the dump material. The oxides gave NP values ranging from -21.25 to 14.00 with a mean value of -3.53 while the MPA ranges from 0.90 to 5.90 with a mean value of 3.60 . The value of the NNP is -7.13 . The negative value confirmed the presence of carbonaceous materials only as traces in the rock while its net acid producing potential falls within an uncertainty zone of 1 . These results suggested that the oxides which are metavolcanic rocks may be acid generating.

Phyllites are the most dominant material in the dump. They constitute about 20 million tonnes. The NP values for the phyllites range from -6.50 to 270.45 with a mean of 39.52 while the MPA 
ranges from 1.60 to 35.30 with a mean value of 9.63. These meta-sediment rocks have a good net neutralising potential of 29.89 and a net acid producing ratio of 4 which is a clear indication of the presence of dolomite-ferroan and ankerite constituting about $50 \%$ and hence its alkalinity according to Perry and Brady (1995) and Skousen et al. (1987). These materials therefore do not contribute to acid generation but rather acid neutralisation.

The schist is about 4.8 million tonnes $(12.0 \%$ of the waste dump volume). The NP values range from -270.00 to 2.75 with a mean of -32.18 and that of the MPA are 1.30 to 150.60 with a mean of 18.26 as shown in Table 2. Its NNP value is $\mathbf{- 5 0 . 4 4}$ and NPR is 2 . These modified ABA values indicate that the schist will be acid generating (Perry and Brady, 1995; Skousen et al., 1987). However, the schist being meta-sediment rocks from the same geological setting as the greywacke and phyllite should not have been acid producing according to the mineralogical analysis and confirmed by Kumi, (1998).

\subsection{Stream Water Analysis}

Generally, Enkansu and Kaw streams at sample points EK1 and WW1 are closer and underneath the waste rocks (Fig. 1). They have near neutral $\mathrm{pH}$ of 7.79 and 7.11 respectively throughout the year. The $\mathrm{pH}$ of water samples at points EK2 and KW1 downstream are also neutral (7.81 and 7.09) as shown in Table 1. The $\mathrm{pH}$ at point KW2 (which flows towards the waste dump) is 7.14. The similarities in $\mathrm{pH}$ values suggest that the streams around the dump have not been affected by any external environmental factors.

The spatial relationship of water chemistry and the waste rocks in the study area is typically interpreted on the basis of the rock mineralogy and elements such as arsenic, iron, copper, lead and zinc. The most dominant element in Enkansu stream is arsenic with a mean value of $0.12 \mathrm{ppm}$ at EK2. Lead and iron concentrations are the next dominant followed by $\mathrm{Cu}$ and $\mathrm{Zn}$ with the least value as shown in Table 1. Arsenic and Lead values are above WHO standards of $0.01 \mathrm{ppm}$ each while the remaining minerals have values lower. At sample point KW2 on the Kaw stream, As concentration is highest with a mean concentration of $0.10 \mathrm{ppm}$ followed by $\mathrm{Fe}$ with a value of 0.06 ppm, $\mathrm{Pb}(0.03 \mathrm{ppm})$ then $\mathrm{Zn}(0.02 \mathrm{ppm})$ and finally $\mathrm{Cu}$ having a concentration of $0.01 \mathrm{ppm}$. The $\mathrm{As}$ and $\mathrm{Pb}$ values are higher than WHO standards. Arsenic concentration is high in both streams. This could be due to the weathering of arsenopyrite, the most abundant auriferous sulphide mineral in all the various rock types and loellingite, an iron arsenic mineral, found in the quartzites. The high value of Fe could similarly be due to the alteration of dolomite-ferroan, ankerite, arsenopyrite and the micas. In the quartzites, the weathering of minor minerals like bornite, jamesonite, chalcopyrite, tetrahedrite and loellingite all can contribute to the presence of $\mathrm{Fe}$ in the streams. When galena and other sulfosalt minerals like boulangerite, jamesonite and bournonite all of which are present in the quartzite are weathered, $\mathrm{Pb}^{2+}$ is released hence the high concentration of $\mathrm{Pb}$ in the streams. These findings agree with earlier work in the study area by previous authors (Kumi, 1988).

\section{Conclusions}

Phyllites and greywackes constitute about 75.0\% of rocks at the Coral Snake Dump. These rocks contain potential acid consuming minerals in contrast to $25 \%$ of materials comprising schist and oxides with negative neutralising potentials and MPA uncertainty. The Coral Snake Dump is not acid generating. This is exemplified by the neutral $\mathrm{pH}$ and low concentrations of heavy metals in the Enkansu and Kaw streams in the immediate environs of the waste dump. However, $\mathrm{Pb}$ and $\mathrm{As} \mathrm{lev-}$ els in the streams within the study area were higher than the acceptable limit.

\section{References}

Amanor, J. A. and Gyapong, W.A. (1988), "The Geology of Ashanti Goldfields Report", Ashanti Goldfields Corporation, (unpublished) pp. 2-26.

Asamoah, V. E., Asiam, E. K. and Kuma, J. S. (2007), "Assessment of a Natural Wetland for the Remediation of Acid Mine Drainage (AMD) at Tarkwa, Ghana", Proceedings of the First International Conference on Environment Research, Technology and Policy, Accra, Ghana, (16-19 July 2007), pp. 27-28.

Blowes, W. D., Ptacek, C. J., Jambor, J. L. and Weisener, C. G. (2005), "The Geochemistry of Acid Mine Drainage", Environmental Geochemistry; Treatise on Geochemistry, (Barbara Sherwood Lollar, ed.), Elsevier 2005, Vol. 9, pp. 149-204.

Brady, K. B. C., and Smith, M. W. (1990), "Pyritic sulfur analyses for coal overburden: differences between laboratories", In: Proceedings 1990 National Symposium on Mining, University of Kentucky, Lexington, Kentucky, pp. 53-58.

Cambridge, M. (1996), "The Development of a Treatment Strategy for Acid Mine Drainage in Minerals Metals and the Environment II", Wheal Jane Minewater Project, the Institute of Mining and Metallurgy, London, 293pp.

Edmunds, W. M. and Smedley, P. L. (1996), "Groundwater Geochemistry and Health: An Overview", Environmental Geochemistry and Health, Geological Society Special Publication, 
Appleton, (R. J. D. Fuge, and G. J. H. McCall, eds.), No. 113, pp. 91-105.

Greenberg A. E., Lenore, S. C. and Eaton A. D. (1992), "Standard Methods for the Examination of Water and Waste Water", $18^{\text {th }}$ edition, pp. 8-34.

Gould, W. D. and Kapoor, A. (2003), "The Microbiology of Acid Mine Drainage", Environmental Aspects of Mine Wastes, (J. L. Jambor, D. W. Blowes and A. I. M. Ritchie, eds.), Vancouver, British Columbia, 2003, Volume 31, pp. 203-226.

Kuma, J. S. (2003), "Passive Treatment of Acid Mine Drainage - Laboratory Studies on a Soil Heap from the Tarkwa Area, Ghana", Ghana Mining Journal, Vol. 7, pp. 46.

Kumi, R. A. K. (1998), "The Petrology of Some Ores from AngloGold Ashanti, Obuasi Mine, Ghana", MSc Thesis, Camborne School of Mines, UK, pp. 19-46.

Nordstrom, D. K. and Alpers, C. N. (1999), "Geochemistry of Acid Mine Waters", The Environmental Geochemistry of Mineral Deposits: Processes, Techniques and Health Issues, Reviews in Economic Geology, in (G. S. Plumlee and M. J. Logdson, eds.), Society of Economic Geologists, Inc., Vol. 6A, pp. 133160.

Pascoe, G. A., Blanchet, R. J. and Linder, G. (1994), "Bioavailability of Metals and As to Small Mammals at a Mining Waste-Water Contaminated Wetland", Architectural Environmental Contamination Toxicology, Vol. 27, pp. 44-50.

Perry, E. F. and Brady, K. B. (1995), "Influence of Neutralisation Potential on Surface Mines Drainage Quality in Pennsylvania", $16^{\text {th }}$ Annual Surface Mine Drainage Task Fore Symp., Morgantown, WV, www.archimede.bibl.ulaval.ca/ archemede/files

Ptacek, C. J. and Blowes, W. D. (2003), "Geochemistry of Concentrated Waters at Mine-Waste Sites", Environmental Aspects of Mine Wastes, (J. L. Jambor, D. W. Blowes and A. I. M. Ritchie, eds.), Vancouver, British Columbia, 2003, Volume 31, pp. 239-252.

Skousen, J. G., Sencindiver, J. C. and Smith R. M. (1987), “A Review of Procedures for Surface Mining and Reclamation in Areas with AcidProducing Materials", Natl. Res. Center for Coal and Energy, Natl. Mine Land Reclamation Centre, Morgantown, WV., http:// www.dep.state.pa.us/dep/deputate/minres/ districts.

Warhurst, A. and Noronha, L. (2000), "Environmental Policy in Mining: Corporate Strategy and Planning for Closure", Lewis Publishers, Washington DC, pp. 118 - 139.

\section{Authors}

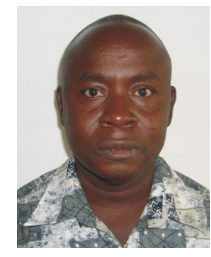

S. A. Ndur is a Senior Lecturer at the University of Mines and Technology, Tarkwa. $\mathrm{He}$ is currently the Head of the Mineral Engineering Department. He obtained his $\mathrm{PhD}$ (Geochemistry) from New Mexico Tech, USA and MSc (Petrochemical Engineering) from Moscow Institute of Oil and Gas, CIS. His research areas are Environmental Pollution and Control, Mine Waste Characterization and Management, and Water Quality Issues. He is a member of Society of Environmental Geochemistry and Health, American Society of Mine Reclamation and Geochemical Society.

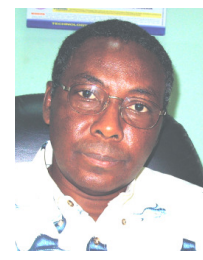

N. A. Amegbey obtained an MSc Degree in Mining Engineering from the Mining Institution of Petrosani, Romania in 1979. In 1987, he obtained a PhD (Dr Ing) from the Technical University of Berlin, Germany. He worked as a Technical Mining Assistant at the former Tarkwa $\triangle$ Goldfields Ltd. and currently is Professor and the Pro Vice Chancellor at the University of Mines and Technology, Tarkwa, Ghana. He lectures and provides consultancy services in Mine Environmental Engineering, Human Factor and Safety Issues. He is a Fellow of the Mine Ventilation Society of South Africa, a member of the German Society of Mining and Metallurgy and a member of the Society for Mining, Metallurgy and Exploration Inc of the United States of America. He serves on a number of international committees on environmental issues.

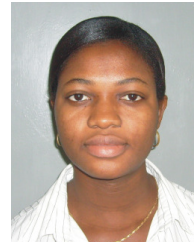

V. E. Frempong (Mrs) is a lecturer at University of Mines and Technology. She holds MPhil and BSc. (Hon) in Mineral Engineering from UMaT and KNUST respectively. Her research area include; Environmental impact of Mining and its Management, Waste Management and Mineral processing. She is a specialist in Acid Mine Drainage Management and Alluvial Mining. 